\title{
SUPPORTING INFORMATION \\ Interactions of Hepatitis B Core Antigen and Peptide Inhibitors
}

Kah Fai Tang, Mohd Puad Abdullah, Khatijah Yusoff, Wen Siang Tan

\section{CONTENTS}

S2: Electron micrograph of hepatitis B core particles.

S3: A schematic representation of chemical cross-linking reaction. 


\section{Electron micrograph of hepatitis B core particles}

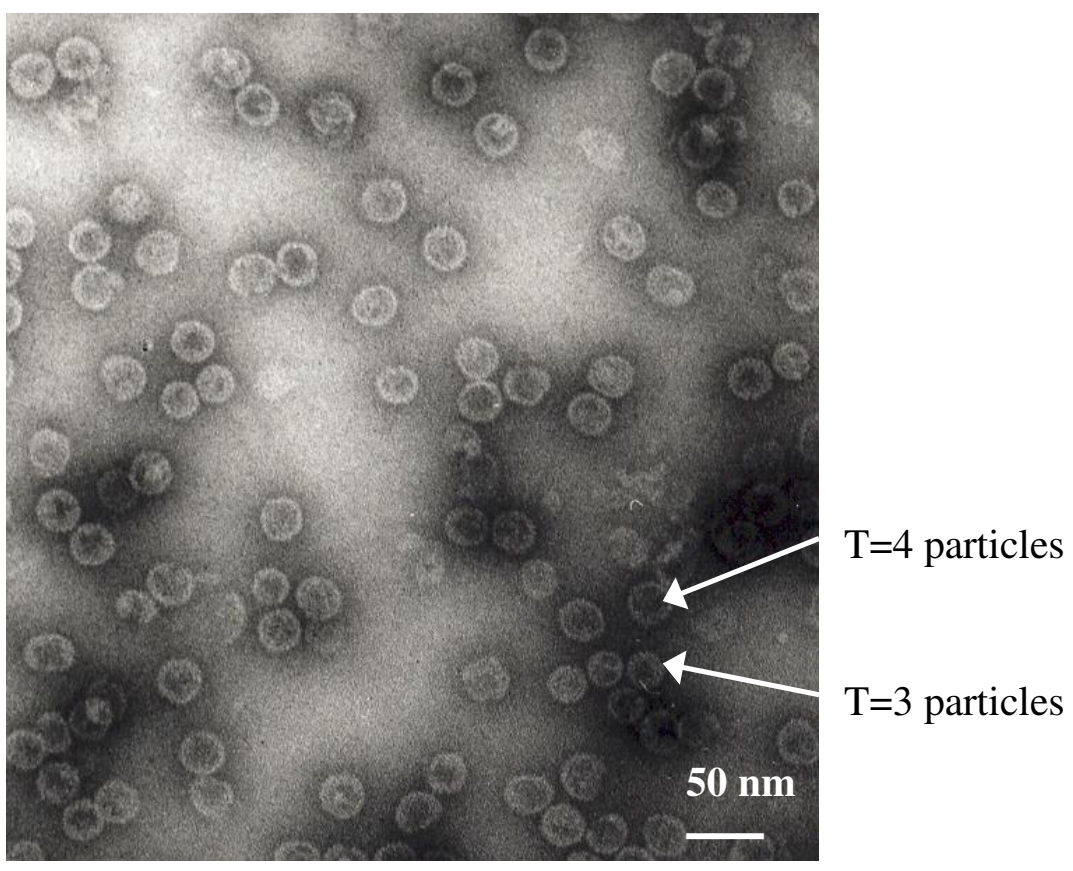

Purified $\mathrm{HBcAg}$ particles were negatively stained with methylamine tungstate and viewed under the Hitachi H-7100 transmission electron microscope. 


\section{A schematic representation of chemical cross-linking reaction}<smiles>CCN=C=NCCC[NH+](C)C</smiles><smiles>NCCCCC(N)C(=O)O</smiles>

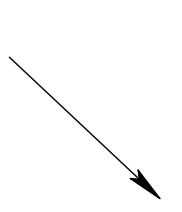

1-ethyl-3-(3-dimethylaminopropyl) carbodiimide hydrochloride (EDC)

Lysine (Lys)<smiles>C=C(C)C(N)CC(=O)OC(=NCC)NCCC[NH+](C)C</smiles><smiles>NC(CCCCNC(=O)CC(N)C(=O)O)C(=O)O</smiles><smiles>CC(C)C1CC(=O)N(O)C1=O</smiles>

$N$-hydroxysulfosuccinimide (sulfo-NHS)

formation

Asp or Glu of HBcAg was hypothesized to cross-link Lys from peptide MHRSLLGRMKGA with the coupling cross-linkers, EDC and sulfo-NHS. 